\title{
USE OF LICIT AND ILLICIT DRUGS AT THE UNIVERSITY OF ALFENAS
}

\author{
João Evangelista Fiorini, Adriana Luiza Alves, Luciano Resende Ferreira, Celso \\ Maia Fiorini, Sandro Willian Durães, Ricardo Luiz Diniz Santos, Luiz Carlos do \\ Nascimento, Andréa Mantelo Vicente Geraldini and Cássia de Fátima Ortiz
}

FIORINI JE et al. - Use of licit and illicit drugs at the University of Alfenas. Rev. Hosp. Clín. Fac. Med. S. Paulo 58(4):199206, 2003.

This paper reports the study of drug consumption carried out within the population of undergraduate students from 2 colleges of Alfenas, in the state of Minas Gerais state. Both licit and illicit drugs were studied, including alcohol, tobacco, marijuana, cocaine, heroin, crack, inhalants, glue, tranquilizers, stimulants, and others.

METHODOLOGY: The research included a wide bibliographical search and the application of a questionnaire to approximately $23 \%$ of the students (total of 6500 students).

RESULTS: A total of 1500 students participated in this investigation. The results demonstrated that there was a significant consumption of both licit and illicit drugs. The pattern of drug consumption in the research sample was similar to other investigations conducted in Brazil and in other countries.

DISCUSSION: It was observed that $55 \%$ of the university students use drugs. However, the most surprising finding was that most of the students (88\%) answered "yes" to the inquiry, "Have you already tried any type of drug, including alcohol and cigarettes?" The students revealed that they had taken drugs even prior to the admission to the university. The results suggest clearly that the university environment does not necessarily represent the starting point for student drug consumption.

DESCRIPTORS: Drugs. Toxics. University. Students. Youth.

During the past few years, the consumption of illicit drugs has been increasing considerably among the young Brazilian population. The precocious relationship between drugs and the consumer can be found in several papers in the literature. Among the several factors that account for the growth of distribution and consumption of drugs in this country include the psychosocial factors of youth that are related to the search for freedom and fast, easy pleasure ${ }^{1-7}$.

The individuals involved with the sale and distribution of drugs seek high school and undergraduate students. Studies were performed concerning the influence of gender and age regarding the consumption of drugs in Brazil; the authors verified that the male population had greater preference for non-prescription drugs, whereas female users tended to prefer psychotropic medications. With regard to the correlation between cigarette use and alcohol abuse, the authors found greater consumption in the male population, with the consumption of alcohol being more frequent than tobacco use $^{6,7}$. It was also observed that of 63

From the Biology and Physiology Lab of Microorganisms, University of Alfenas Alfenas/Minas Gerais, Brazil. Received for publication on October 16, 2002. people hospitalized for drug abuse, $86 \%$ were male, with ages ranging from 12 to 25 years. Except for tobacco and alcohol, marijuana was reported by $66 \%$ of the interviewees as the first psychoactive drug used, serving as the starting point for the use of other drugs $^{7}$. In São Paulo, the incidence of alcoholism is 8 times greater in adult men, but it has grown faster among the women $^{2,3}$.

Among the main effects caused by drugs such as cocaine, marijuana, LSD, ecstasy, mushrooms, glues, and amphetamines are mydriasis, euphoria and a sensation of well being, hallucinations, delirium, excitement, anguish, anxiety, fatigue, arrhythmia, aggres- 
siveness, convulsion, bronchitis, infertility, thirst, hunger, insomnia, nausea, neuronal degeneration, renal failure, and death. Heroin, however, causes drowsiness, pain relief, torpor, miosis, paralysis, and respiratory and cardiac depression $^{19}$.

From the study of the epidemiology of the use of volatile solvents since 1940 , it was concluded that abuse of this drug is restricted to certain segments of the population, such as ethnic minorities of developing countries $^{8}$. However, in Latin America, the use of volatile solvents has spread and has been increasing in the last years, especially among the youth and poor children ${ }^{3,8}$.

Of the 700 people with ages between 9 and 21 years that were interviewed by the "Instituto Brasileiro de Opinião Pública e Estatística (IBOPE)", 65\% reported use of narcotics, alcohol, or tobacco. Around 50\% of these users reported having tried cocaine, marijuana, and glues before 15 years of age, and $75 \%$ used alcohol and cigarettes before this age ${ }^{21}$.

Studies carried out with 116 patients assisted by the Hospital das Clínicas, Faculty of Medicine, University of São Paulo between 1984 and 1988 indicated a considerable increase of cocaine use in the last 2 years of the study ${ }^{9}$.

The association between the consumption of drugs and juvenile delinquency among university students was studied in Mexico. It was observed that the drug abusers were responsible for significantly more antisocial acts than the non-users. The results from a study involving undergraduate students indicated that the drugs most frequently used were marijuana, amphetamines, and inhalants ${ }^{10,11}$. In Valinhos, São Paulo, heroin was considered the second most frequently used drug by the youths, ahead of marijuana and cocaine, according to research conducted by the Institute of Psychology of San Francisco University. Alcohol associated with another drug was in first place $^{13}$. With regard to violence, a medical study conducted by the Federal University of São Paulo revealed that in the general population, a larger number of violent acts are related to alcohol and cocaine drug addicts ${ }^{23}$.

Among students of middle school from Distrito Federal, involving a sampling of 1448 students, a questionnaire was administered that revealed the prevalence of the use of drugs in the following order: alcohol $(67.2 \%)$, cigarettes $(28.7 \%)$, inhalants $(13.9 \%)$, marijuana $(6.1 \%)$, and cocaine $(1.8 \%)$, which was used mainly by males ${ }^{12}$. In a study of 370 drug users in Belo Horizonte, the most frequently used drug was marijuana ${ }^{18}$.

In greater São Paulo in a study of 1069 university students, it was verified that in first place was alcohol use $(82 \%)$, followed by tobacco $(39 \%)$, inhalants $(28 \%)$, marijuana $(26 \%)$, medications $(17 \%)$, and cocaine $(10 \%)$. A greater probability of single male marijuana users, with a high socioeconomic level, who smoked tobacco and used marijuana for the first time between 13 and 17 years old, was also observed ${ }^{15}$.

The current study was conducted with the objective of verifying the incidence and prevalence of licit and illicit drugs in the university population from the city of Alfenas, Minas Gerais, and the implications for the city in this context.

\section{MATERIALS AND METHODS}

\section{General characterization of the loca- tion where the studies were conducted.}

The city of Alfenas, located in the state of Minas Gerais, was chosen because of the large number of students in relation to the total population (above 10\%), in addition to its tradition as a college city since 1914 . It is also a magnet for high school students and possesses an active night life. Currently, a total of 30 graduate-level courses are held in Alfenas.

\section{Data Collection}

The students were interviewed between the months of May and October of 1999. Students of both genders were from the university classes of the city of Alfenas, with the age group ranging from 18 to 25 years.

\section{Sampling}

Among a total of 6500 students, with 5620 students from the University of Alfenas and 880 from the School of Pharmacy and Dentistry of Alfenas, 1500 questionnaires were distributed, registering a sampling of $23 \%$ of the total university population of the city. These questionnaires were divided proportionally among each institution, course, and period of enrollment and were distributed randomly among the students of each class, in agreement with the protocols established for sample stratification, and then were tabulated in percentiles ${ }^{24}$. After answering the questionnaire, students placed the results in an envelope, which was then sealed. The questionnaires did not contain any type of personal identification. Each questionnaire contained 26 items related to whether the university student had already used any drug, the age and school level when the student used the drug for the first time, the drug type, the continuity of the use, and other information (Addendum I).

\section{RESULTS}

From a total of 6500 resident university students in the city of Alfenas, 1500 were interviewed. Of these, $12 \%$ answered that they had never used 
drugs. The remaining students $(88 \%)$ answered affirmatively that they had already used licit or illicit drugs. From this total, $92 \%$ had used before the entrance to the University, with $14 \%$ first using before 12 years of age, $45 \%$ first using between 13 to 15 years of age, $33 \%$ between 16 to18 years of age, and $8 \%$ after 18 years of age (Fig. 1).

The most commonly used drugs were alcohol, tobacco, and other inhaled drugs, with marijuana being consumed by $17 \%$ of the interviewees (Fig. 2).

At the time of the interview, the interviewed population used the following drugs, in decreasing order: alcohol, tobacco, marijuana, inhalants, and other drugs, on a smaller scale (Fig. 3).

Another important factor observed was the type of the student's living arrangement. Forty-eight percent answered that they lived in fraternity houses, $22 \%$ in hotels or similar, or with colleagues, $19 \%$ with relatives, and $11 \%$ live alone (Fig. 4).

\section{DISCUSSION}

Alfenas is a city located in the south of Minas Gerais, where 2 different college institutions exist - a private one, the University of Alfenas (UNIFENAS) and a public one, the School of Pharmacy and Dentistry of Alfenas (EFOA) - with a total university population of approximately 6500 students.
It is known that a paradigm related to the student population, mainly the university student, exists with regard to the use of legalized and illicit drugs $^{22,5,20,6,10,4,14,2,13}$. Therefore, of 6500 Alfenas college students, 1500 were interviewed, and $12 \%$ affirmed that they had never used any type of drug up to the moment of the research.

It was verified that among the students who answered affirmatively that they had used drugs before, about $92 \%$ had used before admission to the university, especially alcohol and tobacco. This is information of great relevance, since it demonstrates that the university is probably not the starting point for the use of drugs. Of these $92 \%, 14 \%$ affirmed that they had tried drugs before the age of $12,45 \%$ between 13 and 15 years of age, $33 \%$ between 16 and 18 years of age, and only $8 \%$ after the age of 18 .

These data revealed that most of the university population had tried some type of drug even before reaching the legal civil age (78\%), which attests to the great susceptibility of adolescents to drugs. Previous data ${ }^{2,6,7}$ revealed the need for the establishment of preventive programs against the use of drugs in school institutions, with the objective of educating adolescents with regard to the dangerous effects of drug use ${ }^{5}$.

Some studies conducted in the university environment and among high school students have demonstrated the dissemination of illicit drugs, reveal- ing marijuana in first place, followed by cocaine and inhalants ${ }^{1,4,5,16,18}$. In the present study, we found that the use of illegal drugs occurred among the interviewees who had used mostly inhaled drugs $(31 \%)$, followed by marijuana $(17 \%)$. However, among the drugs investigated in this study, the percentage who used alcohol and tobacco was substantially larger than that for all the other drugs, $83 \%$ and $38 \%$, respectively. It could be concluded that the fact that these drugs are legal considerably facilitates their use. With regard to this matter, the U.S. Food Drug Administration (FDA) has recently recommended that tobacco should be considered an illicit drug, since it possesses substances that can cause addiction.

With regard to the current use of drugs, $45 \%$ of the interviewee population answered affirmatively to the questionnaire including the use of alcohol and tobacco. The most consumed drug was alcohol (48\%), followed by tobacco (24\%), marijuana $(16 \%)$, and in fourth place (9\%), inhaled drugs. Most of the students who used multiple drugs used alcohol and tobacco, marijuana and tobacco, alcohol and marijuana, or the 3 drugs together. Seventy-one percent $(71 \%)$ of the university interviewees affirmed that they consider alcohol and tobacco as real drugs, and $50 \%$ of the total interviewees declared that they were against the maintenance of the legal status of the substances.

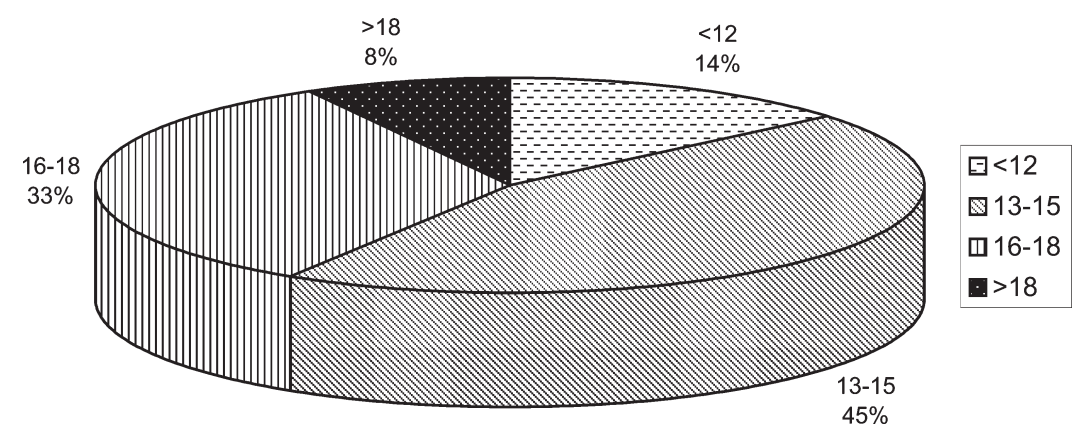

Fig.1 - Percentile distribution in relation to age (in years-old) of those students who had used drugs for the first time. 


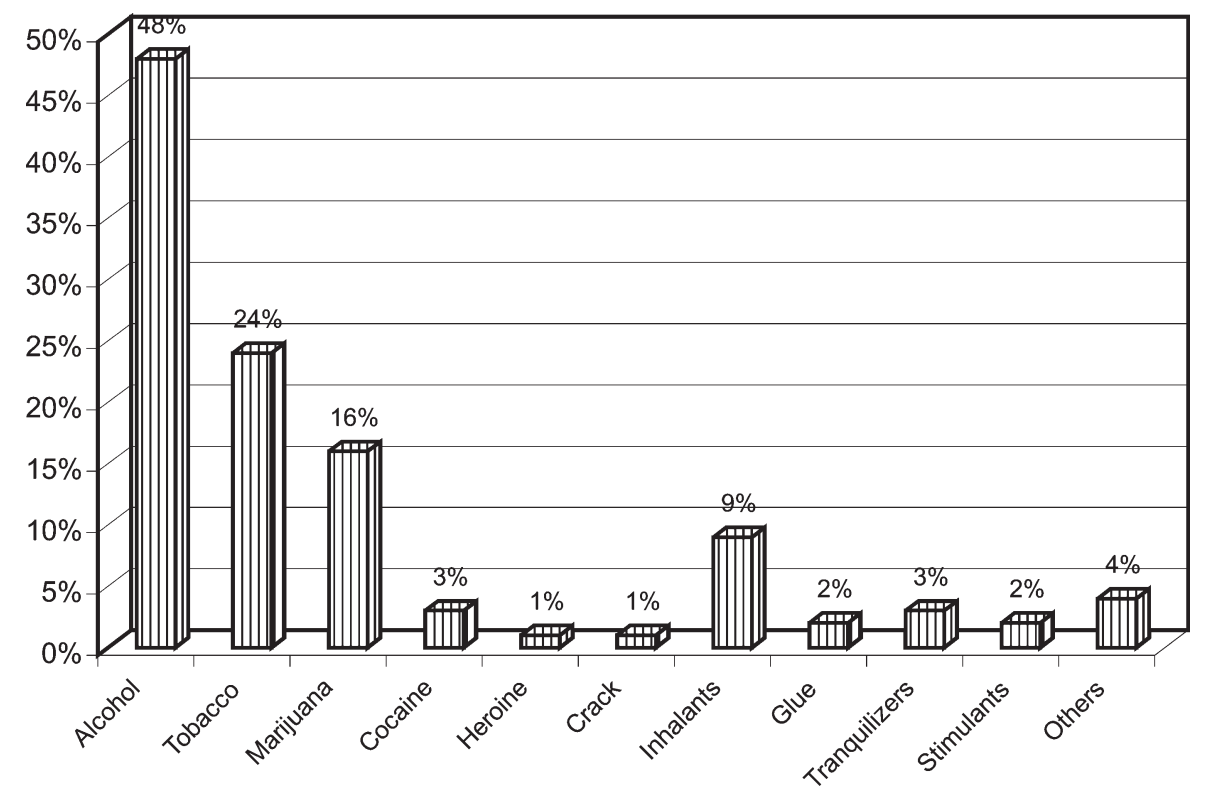

Fig. 3 - Percentile distribution of the drug type that the students use presently.

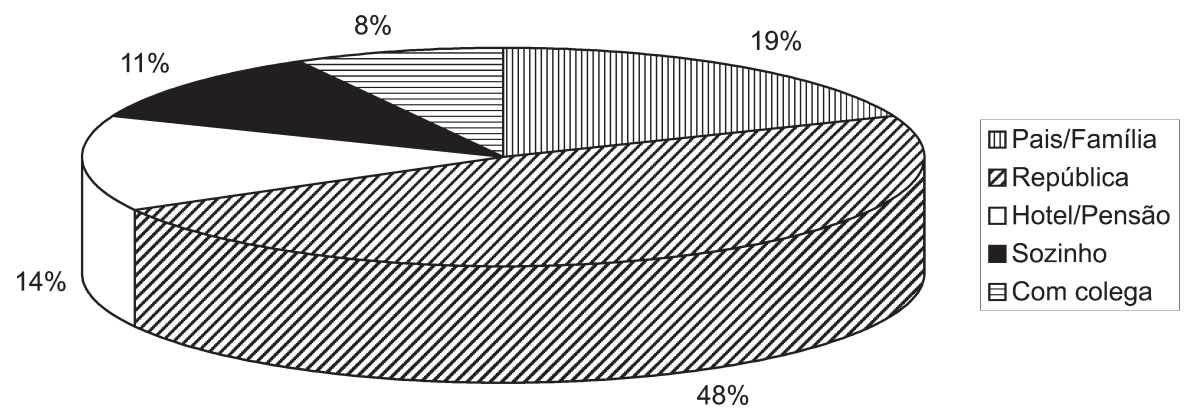

Fig. 4 - Percentile distribution of the type of the university students living in Alfenas.

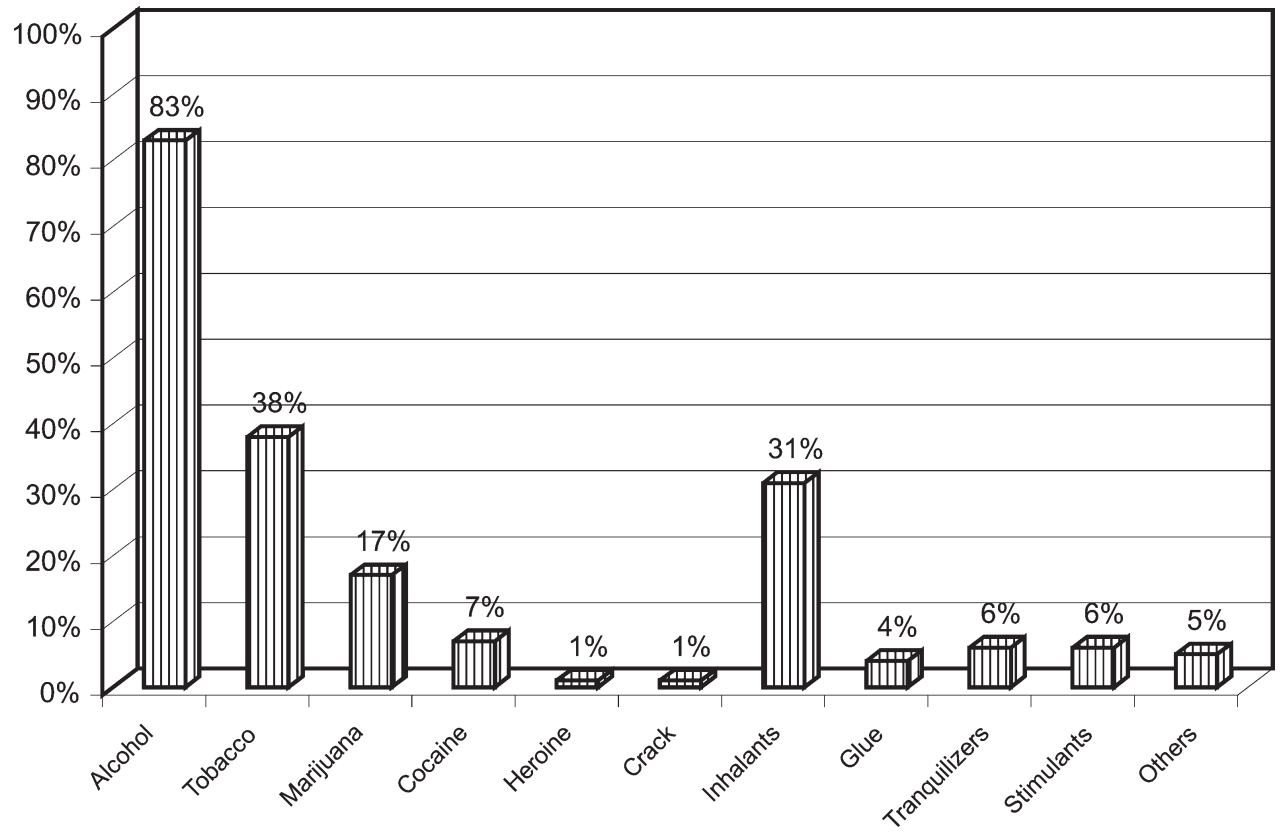

Fig. 2 - Percentile distribution of the drug type that the students had already made use before. 
It was observed that $52 \%$ of the interviewees were female and $48 \%$ were male, with $15 \%$ from Alfenas and the remaining students originating from several different regions of Brazil, demonstrating a great heterogeneity of the student population of Alfenas, and serving as an indicator of the existence of different habits and cultures among the students.

With regard to the place where the interviewees reside in Alfenas, 48\% answered that they live in fraternity houses, $22 \%$ in hotels or similar, or with colleagues, $11 \%$ live alone, and $19 \%$ reside with their relatives. These data demonstrated once again that most of Alfenas university students are coming from other cities, as has been previously described.

In college cities like Alfenas, the increased use of marijuana and cocaine among the students may have 2 explanations: increase of availability and the visibility in society. The media also exerts a great influence in worsening the current picture that has developed among the students. The theme takes evidence in several television programs that insist on showing youth in scenes using and defending the legalization of marijuana.
The existence of a private and a federal university that now attract more than 7000 college students could explain the increase of drug consumption in Alfenas. However this study clearly demonstrated that the use of such drugs had begun before admission to the universities.

Therefore, the "drug problem" in Alfenas, according to the students answers, would not be tied to the existence of the universities, but indeed to a global conjuncture of other factors related with the present times.

\section{CONCLUSION}

The present research revealed that the consumption of drugs in the city of Alfenas exists, but it is less than what was believed by the local population. The obtained data revealed important information concerning the time period of the first experience with drugs. Most of the students had already tried drugs in their hometown prior to the entrance at the university. It can be concluded that the university itself is not serving as a nucleus for the promotion of the first use of drugs. It was also observed that the most used illicit drugs were marijuana and inhalant. The consumption of alcohol and tobacco was quite high among the student interviewees. Presently, approximately half of the men and a third of the women use some type of drug, including alcohol and cigarettes, associated or not with other drugs.

\section{ACKNOWLEDGEMENTS}

We thank Dr. Ivan Freitas and Dr. Lélio Moura Lourenço for the helpful suggestions for the completion of this work; Suheir Kamal Genema, Dr. Paulo Márcio de Faria e Silva, and Dr. Vinícius Vieira Vignoli for the revision of the manuscript; Dr. Alexandre Christófaro Silva for the statistical analysis; and the medical students, Mateus Martins Borges, Carlos Maurício Libânio Diniz, Viviane Pulcineli Freitas, Marco Antônio Carvalho, Túlio César Gonçalves, Ana Paula Donnabella Palmieri, Carlos Alexandre Polônio, Rodrigo José Polônio, Rodrigo Soato, Guilherme de Oliveira Cocolicchio and Denise Rezende for collaboration in the administration of the questionnaires.

\section{RESUMO}

FIORINI JE e col. - Uso de drogas lícitas e ilícitas no meio universitário de Alfenas. Rev. Hosp. Clín. Fac. Med. S. Paulo 58(4):199-206, 2003.

Este trabalho relata um estudo sobre o consumo de drogas realizado em uma população de estudantes em duas universidades na cidade de Alfenas, no estado de Minas Gerais. Tanto drogas lícitas como ilícitas foram consideradas, incluindo álcool, tabaco, maconha, cocaína, heroína, crack, inalantes, cola, tranquilizantes, estimulantes, entre outras.

METODOLOGIA: A pesquisa incluiu uma vasta revisão bibliográfica e a aplicação de um questionário em cerca de $23 \%$ dos acadêmicos (total 6.500).

RESULTADOS: Um total de 1.500 estudantes participaram desta investigação. Os resultados demonstram que há um consumo significativo de tais drogas. Entretanto, o padrão do consumo de drogas na amostra foi seme- 
lhante a outras investigações realizadas no Brasil e em outros países.

DISCUSSÃO: Foi verificado que $55 \%$ dos universitários realmente utilizam drogas. Entretanto, o achado mais surpreendente foi que a maioria dos estudantes $(88 \%)$ que responderam "sim" à indagação "Você já experimentou algum tipo de droga, incluindo álcool e cigarros?" espontaneamente eles revelaram que consumiam tais drogas, porém antes da admissão na Universidade. Este resultado sugere claramente que o ambiente universitá- rio não representa necessariamente o ponto de partida para o consumo de drogas.

DESCRITORES: Drogas. Tóxicos. Estudantes universitários. Adolescentes.

\section{REFERENCES}

1. BARRoS RS, MAGALHÃES MP, OLIVEIRA MA, et al. Avaliação dos efeitos da maconha por usuários de população infantil. Ciênc Cult 1989; 41: 652-7.

2. BARROS RS, ALMEIDA SP, MAGALHÃES et al. - Idéias e imagens suscitadas em estudantes universitários numa pesquisa sobre drogas: uma contribuição ao trabalho preventivo. Bol Psicol 1992; 42: 15-26.

3. BASTOS FIM, LOPES CS, DIAS PP et al. - Perfil de usuários de drogas I: Estudo de características de pacientes do NEPAD/ UERJ - 1986/1987. Rev ABP - APAL 1988; 10: 47-52.

4. BERGONZONI PELAEZ G, RICO O, RAMIREZ J et al. - Uso de drogas entre estudiantes de Cali, Colômbia. Bol Of Sanit Panar 1989; 106: 22-31.

5. BRENES LSV, HAMMES MF, SOLÉ MTV et al. - Drogas ilícitas entre universitários. Rev AMRIGS 1986; 30: 140-3.
6. BUCHER R, TOTOGUI ML - Conhecimento e uso de drogas entre alunos do Brasil. Psicol Teor Pesq 1987; 3: 178-94.

7. BUCHER R, TOTOGUI ML - Influência de sexo e idade em consumidores de drogas no Brasil. Psicol Teor Pesq 1988; 4: 12-21.

8. CARLINI EA, CARLINI COTRIM B, MONTEIRO MG - O uso de solventes voláteis: aspectos epidemiológicos, médicopsicológicos e experimentais. AMB Rev Assoc Méd Bra 1988; 34: $61-8$.

9. CASTEL S, MALBERGIER A - Farmacodependências: estudo comparativo de uma população atendida em serviço especializado: Rev ABP-APAL 1989; 11: 126-32

10. CASTRO SE, GARCiA ZG, ROJAS E et al. - Conducta antisocial y uso en una muestra nacional de estudiantes mexicanos. Salud Pública Mex 1988a; 30: 216-26. 
11. CASTRO SE, GARCIA ZG, ROJAS E et al. - Estudio epidemiológico sobre el uso de drogas y problemas asociados entre la población estudiantil que asiste a los colegios de bachilleres. Salud Ment, 1988b, 11: 35-47.

12. GODOI AM, MUZA GM, COSTA MP et al. - Consumo de substâncias psicoativas entre estudantes de rede privada. Rev Saúde Pública, 1991, 25: 150-6.

13. LEVY C - O Estado de São Paulo, caderno C, 7, 03 de setembro de 1996.

14. MAGALHÃES MP, BARROS RS, OLIVEIRA MA et al. - Padrões de frequência do uso da maconha por estudantes universitários. Rev ABP-APAL, 1989, 11: 35-40.

15. MAGALHÃES MP, BARROS RS, SILVA MA - Uso de drogas entre universitários: a experiência com maconha como fator delimitante. Rev ABP-APAL, 1991, 13: 97-104.

16. MASUR J, CARLINI COTRIM B - Padrão do uso de drogas psicotrópicas precedendo a internação por dependência. Rev ABP-APAL, 1987, 9: 145-50.
17. MONTEIRO FILHO L, FERRAZ MP, MACHADO NR et al. Adolescentes cheiradores de cola J Pediatr 1984; 57: 330-2.

18. MURAD JE - Epidemiologia do abuso de drogas em Belo Horizonte, MG, Brasil. Rev Farm Bioquim 1994; 5: 21-30.

19. MURAD JE - Informações sobre drogas, 1994.

20. PLOTINIK R, AZMUS AD, TANNHAUSER N et al. - Utilização de psicotrópicos por estudantes universitários. Rev Psiqui Méd 1986; 20: 109-13.

21. RYDLE C - O Estado de São Paulo, caderno C, 14 de outubro de 1996.

22. SILVA AA, SOUZA CB, MARINI D et al. - Prevalência do uso de álcool, cigarro e maconha nos alunos da Faculdade de Medicina da Universidade de São Paulo. Arq Coord Saúde Ment Estado de São Paulo 1985; 45: 134-45.

23. TOLEDO JR - Folha de São Paulo, caderno 3, 15 de setembro de 1996.

24. VIEIRA S - Introdução à Bioestatística. $2^{\mathrm{a}}$ ed. Rio de Janeiro, Campus, 1991. p. 204. 


\section{ADDENDUM I}

\section{QUESTIONNAIRE}

01. Gender: male ( ) female ( )

02. Age:____years-old.

03. Race: white ( ) black ( ) other ( )

04. Social Class: A ( ) B ( ) C ( )

05. Procedence: city:

state:

06. Place where he/she lives:

With the parents ( )

Hotel/Bed and Breakfast ( )

With colleague ( )

Fraternity house ( )

Alone ( )

07. Scholarity of the father ( ), of the mother ( )

$A=1$ st degree

$B=2$ nd degree

$\mathrm{C}=3$ rd degree

08. Parents situation:

They live together ( )

Divorced ( )

father has passed away ( )

mother has passed away ( )

09. Have you already tried any type of drug including alcohol and/ or cigarette?

Yes ( ) No ( )

10. Do you consider alcohol and/or cigarette as drugs? Yes ( ) No ( )

11. What age have you tried drugs for the first time? (including alcohol and cigarette): years-old.

12. In what school level? 1st ( ) 2nd ( ) 3rd ( )

13. What drugs have you already tried?

$\begin{array}{llll}\text { Alcohol } & (\text { ) } & \text { Tranquilizers } & (\text { ) } \\ \text { smoking } & (\text { ) } & \text { Stimulants } & (\text { ) } \\ \text { Loló } & (\text { ) } & \text { Marijuana } & (\text { ) } \\ \text { glues } & (\text { ) } & \text { Cocaine } & (\text { ) } \\ \text { Crack } & (\text { ) } & \text { Heroine } & (\text { ) } \\ \text { Inhalant } & (\text { ) } & \text { Other } & (\text { ) }\end{array}$

14. Presently, are you using any drugs?

(including alcohol and cigarette)

Yes ( ) No ( )

15. If you use any drugs, what have lead you to do that?

The companions ( )

Aware of what it causes ( )

Lack of better life option ( )

$\mathrm{He} /$ she riots against family ( )

$\mathrm{He} /$ she riots for the injustices ( )

Search for partners problems solutions ( )

Other ( )
16. Have your parents used drugs before or do they currently use them?

Yes ( ) No ( ) I don't have knowledge ( )

17. What's your relationship with the drugs?

I use frequently and I don't want to leave them ( )

I use frequently and I want to leave them ( )

I don't use, but I have wish for them ( )

I use eventually ( )

I live in function of the drugs ( )

Other ( )

18. Do you easily obtain the drugs that you consume? Yes ( ) No ( )

19. How do you get the money for the drugs?

I work ( )

I make small thefts ( )

I take my parents' money ( )

Sells personal objects ( )

I obtain from another sources ( )

20. Do your parents have knowledge that you are a drug user? Yes ( ) No ( )

21. Do you maintain dialogue with your parents about Yes ( ) No ( )

22. Do you have siblings that make use of drugs? Yes ( ) No ( )

23. What is the location where does he frequently make use of drugs:

In its own house ( )

In the school ( )

In the streets ( )

In the friends' house ( )

In bars and night-clubs ( )

Other ( )

24. Are you aware of the risks that the drugs offer to your health? Yes ( ) No ( ) In terms ( )

25. Do you intend of using drugs? Yes ( ) No ( ) In terms ( )

26. Do you agree with the legalization of the drugs? Yes ( ) No ( ) In terms ( )

Obs.: In case if you want to make any comments, please write in this space: 